\title{
Composition and quantity of cytotoxic waste from oncology wards: A survey of environmental characterization and source management of medical cytotoxic waste
}

\author{
Y. Ghafuri ${ }^{1,2}$ and R. Nabizadeh ${ }^{3 *}$ \\ ${ }^{1}$ Department of Environmental Health Engineering, School of Public Health, International Campus, Tehran \\ University of Medical Sciences, Tehran, Iran \\ ${ }^{2}$ Environmental Research Center, Qom University of Medical Science, Qom, Iran \\ ${ }^{3}$ Department of Environmental Health Engineering, School of Public Health. Tehran University of Medical \\ Sciences, Tehran, Iran
}

\begin{abstract}
Interest in waste drugs as a part of hospital waste in relation to their negative impact on the environment has increased during the past years. Cytotoxic drugs play an important role in the treatment of various neoplastic conditions and are most often used in specialized departments such as oncology and radiotherapy units. In this study an initial inventory of pharmaceuticals and unused pharmaceuticals including hazardous waste drugs and antineoplastic (cytotoxic) chemotherapeutics was provided. By providing a questionnaire, the rate of cytotoxic consumption, residuals of drugs, vial and syringes, needles, gloves and the other cytotoxic waste was measured during a 30-day period in two oncology wards of Qom hospitals in Iran. The results determined that mean production rate of medical waste in two hospital is $435 \mathrm{~kg} / \mathrm{d}$ and equal to $1.73 \mathrm{~kg} / \mathrm{bed} / \mathrm{d}$, including: $97 \%$ infection waste (1.67 kg/ $\mathrm{bed} / \mathrm{d}), 2.5 \%$ sharp and syringe waste $(43.25 \mathrm{~g} / \mathrm{bed} / \mathrm{d})$ and $0.5 \%$ pharmaceutical waste $(8.65 \mathrm{~g} / \mathrm{bed} / \mathrm{d})$. The rate of cytotoxic waste in the investigated hospitals was $293.5(\mathrm{gr} / \mathrm{d})$ and equal to 0.07 total medical waste. On the other hand the average rate of cytotoxic waste in the oncology departments was $21.5 \mathrm{gr} / \mathrm{bed}$ and $16.5 \mathrm{gr} /$ patient. The results determined that over $66 \%$ of residuals cytotoxic drug compounds can be converted in to nontoxic and no genotoxic by chemical degradation. Lack of awareness of health hazards, insufficient financial and human resources and poor control of waste disposal are the most common problems connected with healthcare wastes.
\end{abstract}

KEY WORDS: СYTOTOXIC-WASTE-QOM-COMPOSITION

\section{ARTICLE INFORMATION:}

*Corresponding Author:

Received $12^{\text {th }}$ July, 2017

Accepted after revision $28^{\text {th }}$ Sep, 2017

BBRC Print ISSN: 0974-6455

Online ISSN: 2321-4007 CODEN: USA BBRCBA

Thomson Reuters ISI ESC and Crossref Indexed Journal

NAAS Journal Score 2017: 4.31 Cosmos IF: 4.006

๑ A Society of Science and Nature Publication, 2017. All rights reserved.

Online Contents Available at: http//www.bbrc.in/

DOI: $10.21786 / \mathrm{bbrc} / 10.3 / 17$ 


\section{INTRODUCTION}

Healthcare activities can lead to the generation of hazardous of wastes that may have adverse effects on human health and on the environment. Interest in waste drugs as a part of hospital waste in relation to their negative impact on the environment has increased during the past years. Many of the chemicals and pharmaceuticals used in health care are hazardous. They are commonly present in small quantities in health-care waste, whereas larger quantities may be found when unwanted or outdated chemicals and pharmaceuticals are sent for disposal, (Drug, 2015).

Considering the classification of hazardous healthcare waste by WHO the Categories of hazardous healthcare waste are: sharps, Infectious, Pathological, Pharmaceutical and cytotoxic, Chemical waste, and Radioactive waste. The types and nature of hospital waste depends upon the nature of the hospital and the service available in hospital (WHO, 2014). Exposure to genotoxic substances in health care may also occur during the preparation of, or treatment with, particular drugs or chemicals. The main pathways of exposure are inhalation of dust or aerosols, absorption through the skin, ingestion of food accidentally contaminated with cytotoxic drugs, ingestion as a result of bad practice, such as mouth pipetting, or from waste items. Exposure may also occur through contact with body fluids and secretions of patients undergoing chemotherapy. Genotoxic waste is highly hazardous and may have mutagenic, teratogenic, or carcinogenic properties. Genotoxic waste may include certain cytostatic drugs, vomit, urine, or faeces from patients treated with cytostatic drugs, chemicals, and radioactive material (Ansell, 2015).

Cytotoxic drugs (CDs) are primarily used as anti- cancer drugs because they are toxic to cells. These drugs have been associated with human cancers at high (therapeutic) levels of exposure and are carcinogens and teratogens in many animal species. They are most often used in specialized departments such as oncology units, whose main role is cancer treatment. Cytostatic drugs can be categorized as: alkylating agents which cause the alkylation of DNA nucleotides, leading to the cross-linking and miscoding of the genetic stock; antimetabolites which inhibit the biosynthesis of nucleic acids in the cell; and mitotic inhibitors which prevent cell replication (Antell, 2013). Medical waste is incorrectly managed throughout the majority of hospitals in Iran. Healthcare workers are not trained to conceive that a large proportion of medical waste generated in hospitals is Noninfectious waste. A structured waste management strategy together with clear definitions and staff training will lead to a decrease in waste volumes, and consequently to a reduction of costs in healthcare settings. Generated amounts of the health care waste are not available (for example Ireland) or the defined amount of wastes is too low (for example Bulgaria, Finland) or too high (in case of Belgium). Among other issues, this might be an indication of improper waste management practice or poor data collection in the country; Askarian et al, 2010; Farzadkia et al, 2009; Abduli, 2010 Nabizadeh, 2016).

In recent years, the rate of cancer disease and consumption of cytotoxic drugs in oncology wards of Qom hospital has increased. In this work composition, the quantity and possibility of chemical degradation of cytotoxic drug waste have been studied.

\section{MATERIALS AND METHODS}

This study was performed in 2015, in the oncology wards of two hospitals in Qom, Iran including Shahid Beheshti Hospital with 400 active beds and Hazrat Masoumeh Hospital with 120 active beds, located in the central part of Qom Province. The studied hospitals provide general medical, surgical, maternity, pediatric, and a range of specialist services.

Considering the methods of medical waste management and the main generation of medical waste in the two investigated hospitals, the total medical waste was classified in three categories: infection, sharp and Pharmaceutical waste. Several methods were used to collect data, namely site visits, interviews, and questionnaires. An initial inventory of pharmaceuticals and unused pharmaceuticals including hazardous waste drugs and antineoplastic (cytotoxic) chemotherapeutics was provided. Moreover, data collection consisting of healthcare waste generation, separation, collection, storage, transportation, and disposal was performed during site visits to the hospitals. With the cooperation and coordination of the personal and management of hospitals and using the questionnaire, the rate of cytotoxic consumption on, residuals of drugs, vial and syringes, needles, gloves and the other cytotoxic waste was measured in a 30 day period.

The Chemical degradability of cytotoxic waste was assessed with exposure to chemical oxidants (WHO, 2014). Specific physico-chemical properties such as: dissociation constant (pKa), solubility, octanol-water partition coefficient (Kow) and organic carbon partition coefficient (Koc), bio-concentration factor (BCF), atmospheric hydroxyl radical reaction rate and photolysis tendency play critical roles in determining the environmental behaviors and fate of cytotoxic waste (Cheng et al, 2009; Andrew et al, 2008; Toolaram et al, 2014; Zhang et al, 2013; Besse et al, 2012). The Prediction of environmental fate and other physico-chemical properties was carried by a theoretical model (EPI Suite 4.1) 
(EPA, 2014). Two criteria contain octanol-water partition coefficient (Kow) and solubility was considered. A $\operatorname{logKow}<1$ suggests that the compounds are highly mobile in an aquatic environment. About solubility, adding or existance of polar functional groups that increase of hyrophilicity of drug compound were considered (Zhang et al, 2013; Besse et al, 2012).

\section{RESULTS AND DISCUSSION}

\section{QUANTITIES OF MEDICAL WASTE GENERATION}

There were 120 active beds in the Hazrat Masoumeh Hospital and the rate of medical waste was identified as $220 \mathrm{~kg} / \mathrm{d}$. Also there were 400 active beds in Shahid Beheshti Hospital with the medic production rate of $650 \mathrm{~kg} / \mathrm{d}$. Table 1 shows the average daily production of total medical in two hospitals. Medical waste from Hazrat Masoumeh hospital equaled $1.83 \mathrm{~kg} /$ occupied bed/d, of which $96.36 \%$ was infectious, 3.1\% sharp waste and 0.45\% Pharmaceutical waste .Shahid Beheshti hospital medical waste was $1.62 \mathrm{~kg} /$ occupied bed/d of which 98\% was infectious, 1.7\% sharp and 0.3\% pharmaceutical waste.

\section{Category of cytotoxic waste}

The rate of cytotoxic waste was assessed in oncology wards of two hospitals separately. The results are shown in table 2 .

Table 3 shows the mean production rate and category of cytotoxic drug waste in the hospitals under study.

\section{Characteristics and chemical degradation of cytotoxic drugs}

Twelve chemical structures of conventional cytotoxic drug compounds used in the oncology wards of hospi- tals under study were assessed. The results pertaining to the solubility and degradability of cytotoxic drug when exposed to chemical oxidants, the results are shown in Table 4.

Results of the present study determined that mean production rate of medical waste in the two hospitals was $435 \mathrm{~kg} / \mathrm{d}$ and equal to $1.73 \mathrm{~kg} / \mathrm{bed} / \mathrm{d}$, including: $97 \%$ infection waste $(1.67 \mathrm{~kg} / \mathrm{bed} / \mathrm{d}), 2.5 \%$ sharp and syringe waste $(43.25 \mathrm{~g} / \mathrm{bed} / \mathrm{d})$ and $0.5 \%$ pharmaceutical waste $(8.65 \mathrm{~g} / \mathrm{bed} / \mathrm{d})$. The results of study about hospital waste management status in Iran by farzadkia and at al showed that the waste generation rate was 2.5 to $3.01 \mathrm{~kg}$ bed(-1) day(-1), which included 85 to $90 \%$ of domestic waste and 10 to $15 \%$ of infectious waste. Waste generation rate in the hospitals varied from 1.25 to $14.8 \mathrm{~kg} /$ bed/d (Zhang et al, 2013; Besse et al, 2012).

Medical waste production depends on factors such as type of hospital, number of beds, socio-economic and cultural status of patients and waste management processes (Cheng et al, 2009). In Thailand, Italy, USA, India, Peru, Vietnam, and Tanzania 1, 3-5, 5-7, 0.5-2, $0.76-2.6,1.42$, and $0.84 \mathrm{~kg} / \mathrm{bed} / \mathrm{d}$, of medical waste are respectively generated, are generated (Dehghani, 2008). According to a study of the composition and production rate of pharmaceutical and chemical waste in Greece, the production rate for total pharmaceutical waste was $7.48 \mathrm{~g} / \mathrm{bed} / \mathrm{d}$ (Voudrias, 2012).

Results of Table 2 and 3 exhibited that the rate of cytotoxic waste in the investigated hospitals was $293.5(\mathrm{~g} / \mathrm{d})$ equal to 0.07 total medical waste. On the other hand the average rate of cytotoxic waste on the in the oncology departments was $21.5 \mathrm{~g} /$ bed equal to $16.5 \mathrm{~g} /$ patient. Moreover, the total amount of generation waste from cytotoxic drug residuals was $120.2 \mathrm{mg} / \mathrm{d}$ (mean $4.92 \mathrm{mg} / \mathrm{d}$ and standard deviation $\pm 8.88 \mathrm{mg} / \mathrm{d}$ for any cytotoxic drug) and the total amount other

\begin{tabular}{|l|c|c|c|c|c|}
\hline \multicolumn{2}{|l|}{ Table 1. Estimated medical waste generation rate of hospital waste for two hospitals investigated } \\
\hline $\begin{array}{l}\text { Name of } \\
\text { hospitals }\end{array}$ & $\begin{array}{c}\text { Number of } \\
\text { active beds }\end{array}$ & $\begin{array}{c}\text { Rate of total medical } \\
\text { waste }(\mathrm{kg} / \mathrm{d})\end{array}$ & $\begin{array}{c}\text { Separation of medical waste } \\
\text { waste }(\mathrm{kg} / \mathrm{d})\end{array}$ & $\begin{array}{c}\text { Sharp waste } \\
(\mathrm{kg} / \mathrm{d})\end{array}$ & $\begin{array}{c}\text { Pharmaceutical } \\
\text { waste(kg/d) }\end{array}$ \\
\hline Hazratmasoumeh & 120 & 220 & 212 & 7 & 1 \\
\hline Shahidbeheshti & 400 & 650 & 637 & 11 & 2 \\
\hline
\end{tabular}

\begin{tabular}{|c|c|c|c|c|}
\hline \multirow{2}{*}{$\begin{array}{l}\text { Name of } \\
\text { hospitals }\end{array}$} & \multirow{2}{*}{$\begin{array}{c}\text { number of active beds in } \\
\text { oncology department }\end{array}$} & $\begin{array}{l}\text { rate of total } \\
\text { cytotoxic waste }\end{array}$ & $\begin{array}{c}\text { rate of cytotoxic } \\
\text { waste }\end{array}$ & $\begin{array}{c}\text { rate of cytotoxic } \\
\text { waste }\end{array}$ \\
\hline & & $(\mathrm{gr} / \mathrm{d})$ & (gr/bed/d) & (gr/patient/d) \\
\hline Hazrat masoumh & 12 & 337 & 22.5 & 18 \\
\hline Shahid beheshti & 15 & 250 & 20 & 15 \\
\hline
\end{tabular}




\begin{tabular}{|l|l|c|c|c|}
\hline \multicolumn{6}{|l|}{ Table 3. Average production rate and category of cytotoxic drug waste in hospitals investigate } \\
\hline Number & Drug compound & $\begin{array}{c}\text { Daily average } \\
\text { dosage used } \\
(\mathrm{mg} / \mathrm{d})\end{array}$ & $\begin{array}{c}\text { Waste from residual } \\
\text { of cytotoxic drug } \\
\text { (mg/d) }\end{array}$ & $\begin{array}{c}\text { Rate of other cytotoxic waste } \\
\text { that produced from expose to } \\
\text { cytotoxic drug (gr/d) }\end{array}$ \\
\hline 1 & Cytarabine & 120 & 8 & 25 \\
\hline 2 & Etoposide & 100 & 6 & 18 \\
\hline 3 & Vincristine & 170 & 8 & 24 \\
\hline 4 & Carboplatin & 70 & 9 & 28 \\
\hline 5 & oxaliplatin & 27 & 2.7 & 6 \\
\hline 6 & Fluorouracil (5-FU) & 15 & 1.5 & 12 \\
\hline 7 & Cisplatin & 120 & 3 & 20 \\
\hline 8 & Cyclophosphamide & 170 & 18 & 26 \\
\hline 9 & bleomycin & 60 & 7 & 30 \\
\hline 10 & Erinotekan & 130 & 13 & 10 \\
\hline 11 & mesna & 200 & 15 & 25 \\
\hline 12 & Dacarbazine (DTIC) & 50 & 8 & 10 \\
\hline 13 & Methotrexate & 130 & 10 & 25 \\
\hline 14 & L-asparaginase & 80 & 8 & 282 \\
\hline 15 & Ifosfamide (Ifex) & 170 & 17 & \\
\hline Sum & & 1512 & 120.2 & \\
\hline & & & & \\
\hline
\end{tabular}

cytotoxic waste generated from contact was $282 \mathrm{~g} / \mathrm{d}$ (mean $7.92 \mathrm{~g} / \mathrm{d}$ and standard deviation $\pm 18.8 \mathrm{~g} / \mathrm{d}$ for any cytotoxic drug). Figure1 indicated that maximum production rate of daily average administrated dosage of cytotoxic drugs is related to Mesna $(200 \mathrm{mg} / \mathrm{d})$ and maximum production rate for waste from residuals is related to Cyclophosphamide (18mg/d)
Figure 2 with $\mathrm{R}^{2}=0.59$ and Figure 3 with $\mathrm{R}^{2}=$ 0.47 exhibited a small correlation between daily average dosage and waste from residuals of cytotoxic drug and a smaller one daily average dosage and rate of other cytotoxic waste generated from contact.

The results of the by Tasakona showed that the rate of cytotoxic waste was $120 \mathrm{l} /$ day and 0.03 from total

\begin{tabular}{|c|c|c|c|}
\hline $\begin{array}{l}\text { Cytotoxic drug } \\
\text { compound }\end{array}$ & Chemical Formula & $\begin{array}{l}\text { Solubility of cytotoxic } \\
\text { drugs with consider to polar } \\
\text { functional group }\end{array}$ & $\begin{array}{l}\text { Hydrophilicity of } \\
\text { cytotoxic drug with } \\
\text { consider to(Kow) }\end{array}$ \\
\hline Carboplatin & $\mathrm{C}_{15} \mathrm{H}_{18} \mathrm{~N}_{4} \mathrm{O}_{3}$ & + & + \\
\hline Vincristine & $\mathrm{C}_{46} \mathrm{H}_{56} \mathrm{~N}_{4} \mathrm{O}_{1}$ & + & + \\
\hline Cyclophosphamide & $\mathrm{C}_{7} \mathrm{H}_{15} \mathrm{Cl}_{2} \mathrm{~N}_{2} \mathrm{O}_{2} \mathrm{P}$ & + & - \\
\hline Cisplatin & $\mathrm{H}_{6} \mathrm{Cl}_{2} \mathrm{~N}_{2} \mathrm{Pt}$ & + & + \\
\hline Bleomycin & $\mathrm{C}_{55} \mathrm{H}_{84} \mathrm{~N}_{17} \mathrm{O}_{21} \mathrm{~S}_{3}$ & + & - \\
\hline Etoposide & $\mathrm{C}_{29} \mathrm{H}_{32} \mathrm{O}_{13}$ & + & + \\
\hline Cytarabine & $\mathrm{C}_{9} \mathrm{H}_{13} \mathrm{~N}_{3} \mathrm{O}_{5}$ & + & + \\
\hline Erinotekan & $\mathrm{C}_{33} \mathrm{H}_{38} \mathrm{~N}_{4} \mathrm{O}_{6}$ & + & + \\
\hline Mesna & $\mathrm{C}_{2} \mathrm{H}_{5} \mathrm{NaO}_{3} \mathrm{~S}_{2}$ & - & - \\
\hline Dacarbazine (DTIC) & $\mathrm{C}_{6} \mathrm{H}_{10} \mathrm{~N}_{6} \mathrm{O}$ & - & + \\
\hline Fluorouracil (5-FU) & $\mathrm{C}_{4} \mathrm{H}_{3} \mathrm{FN}_{2} \mathrm{O}_{2}$ & - & + \\
\hline Methotrexate & $\mathrm{C}_{20} \mathrm{H}_{22} \mathrm{~N}_{8} \mathrm{O}_{5}$ & + & + \\
\hline
\end{tabular}




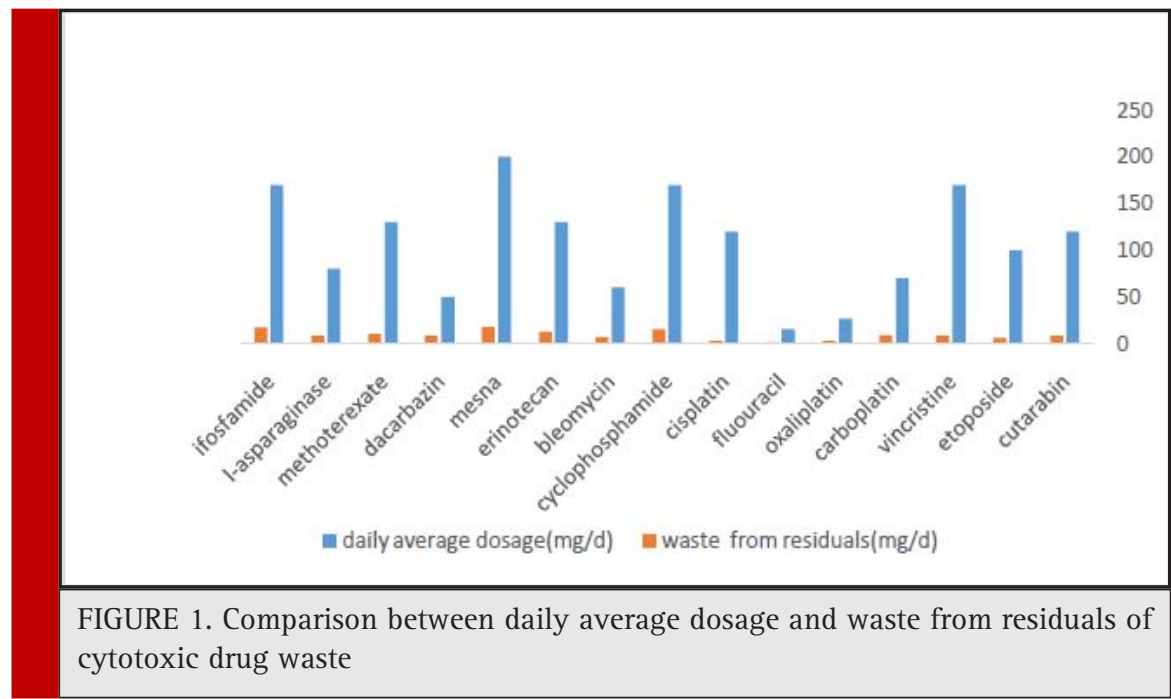

amount of medical waste, was different (medical waste density in Iran is $170 \mathrm{~kg} / \mathrm{m}^{3}$ ) but approve the Bill Brewer, Andrew Antel study that rate of cytotoxic waste from chemutraputic drug such as Cyclophosphamide (CP), Mitomycine, Mycophenolate was $0.08 \mathrm{ib} / \mathrm{bed} /$ day (Tsakona, 2010). Results of a survey by Evanglos Vondarials, suggested that rate of pharmaceutical's waste was $3.9 \%$ of hazardous waste in agreement with our results (Voudrias, 2012).

\section{Cytotoxic waste residue as a source of cytotoxic drugs in the Environmental}

With survey of medical waste management in two hospitals, direct disposal as the municipal solid waste is still a common way for the unused pharmaceuticals. Four primary sources (hospital effluent, household wastewater, and production discharge and drug waste disposal) of cytostatic residues. Hospitals produce large quantities of chemically- and which carry high potential ecotoxicity, and should not be considered as possessing the same pollutant nature as urban wastewater. The measured cytostatic levels in hospital sewage indeed correlated with the daily consumption and the pharmacokinetic excretion pattern (Zhang et al, 2013; Besse et al, 2012). At present study, results of prediction model (EPI Suite 4.1) was shown that, cytotoxic drug waste residue including: Carboplatin, Vincristine, Cyclophosphamide, Cisplatin, Bleomycine, Etoposide, Cytarabin, Erinotekan and Methoterexate with considering excration pattern and discharge in to hospital sewage, have been increased toxicity of aquatic environment (EPA, 2013).

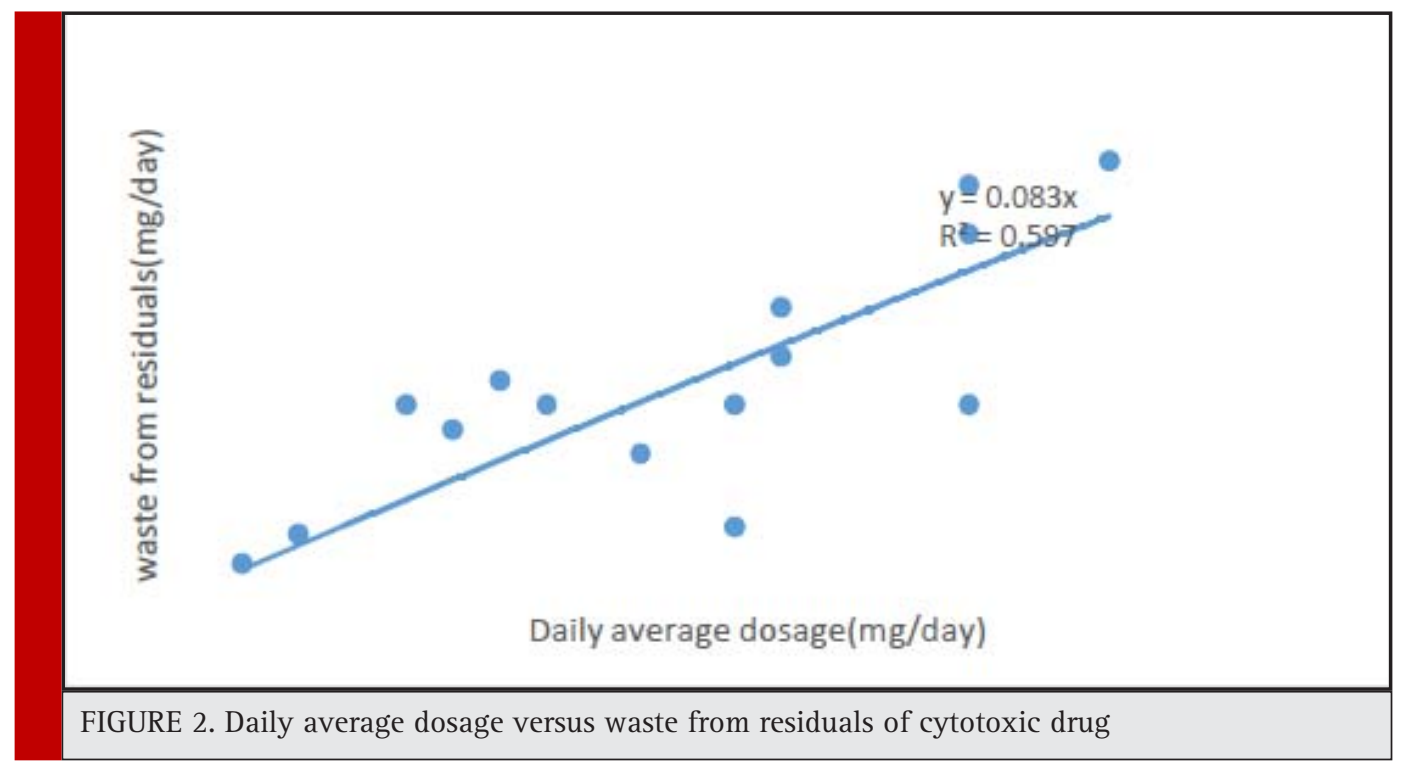




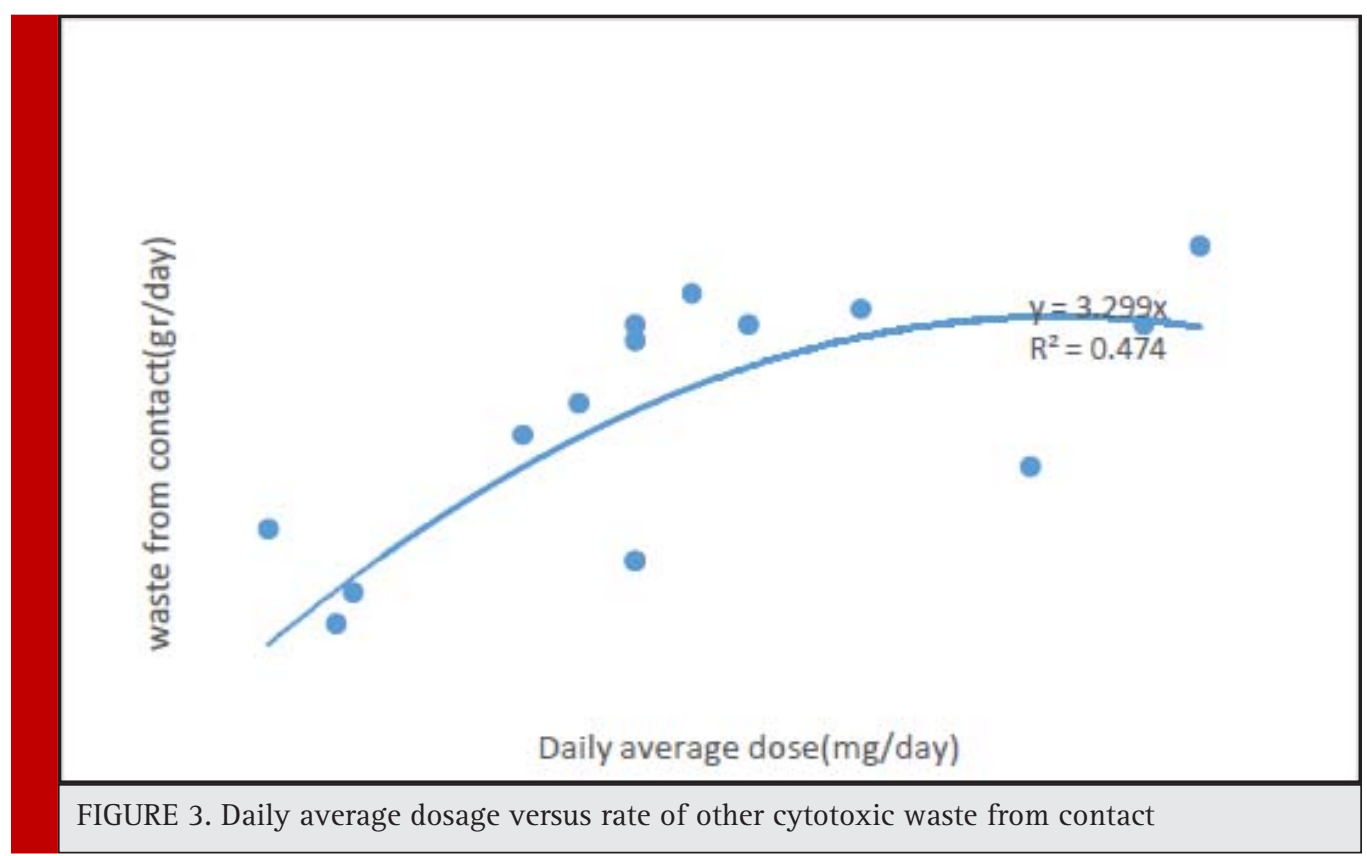

\section{Implementation of cytotoxic waste management plan and selection of treatment methods}

Risk control measures for cytotoxic waste management including: identification, containment and segregation. Other requirements contain handling or storage of cytotoxic waste, disposal and treatment, in the process of waste management plan must be considered.

The choice of treatment system involves consideration of waste characteristics, technology capabilities and requirements, environmental and safety factors, and costs, many of which depend on local conditions. The results of study about_solubility and degradability of conventional cytotoxic waste is depicted in Table 4 . For decrease of environmental risks and degradation of these compounds by chemical degradation methods as an option that appropriate for developing countries were investigated. results determined that over $66 \%$ of residuals cytotoxic drug compounds can be converted in to nontoxic and no genotoxic by chemical degradation including oxidation by potassium permanganate $\left(\mathrm{KMNO}_{4}\right)$ or sodium hypochlorite (NaCLO,5.25\%) readily available in Iran hospitals. It must be noted that this process is not suitable for other cytotoxic waste containing vial, syringe, and gloves for which the appropriate process is handling (Drug, 2015).

\section{CONCLUSION}

The implementation of medical waste management is one of the most significant healthcare issues currently requiring attention in Iran. Hospital waste materials pose a wide variety of health and safety hazards for patients and healthcare workers. Many of hospitals in Iran have neither a satisfactory cytotoxic waste disposal system nor a waste management and disposal policy. Provision of a cytotoxic waste management planning and monitoring systems in hospitals is a prerequisite issue for effective reduction of health care waste associated risks.

\section{ACKNOWLEDGEMENTS}

This research has been carried by cooperation of Qom University of Medical Science and the authors express gratitude to all hospital staff of Qom University of Medical Science for their support through this study.

\section{REFERENCES}

Abduli M.A., ET. Al, 2010. Municipal Waste Reduction Potential and Related Strategies in Tehran, Int. J. Environ. Res., 4(4): 901-912, 1735-6865.

Almuneef, M., Memish, Z.A., 2003. Effective medical waste management: it can be Done, American Journal of Infection Control, 31, 188-192.

Andrew C. Johnson, Monika D. Ju rgens a, 2008. Richard J. Williams a, Kummerer. K, Kortenkamp. A, John P. S. ,Do cytotoxic chemotherapy drugs discharged into rivers pose a risk to the environment and human health ? An overview and UK case study, Journal of Hydrology, 348, 167- 175

Anju Priya Toolaram, Klaus Kümmerer.2014. Environmental risk assessment of anti-cancer drugs and their transformation products: A focus on their genotoxicity characterization-state 
of knowledge and short comings. 2014- Mutation Research 760, 18-35

Ansell Healthcare Products LLC, 2015. Handling Cytotoxic Drugs; A HEALTH AND SAFETY REVIEW. www.ansellhealthcare.com

Bdour, A., Altrabsheh, B., Hadadin, N., Al-Shareif, M., 2007. Assessment of medical wastes management practice: a case study of the northern part of Jordan. Waste Management, 27, 46-759

Blenkharn, J.I, 2007. Standards of clinical waste management in hospitals - a second look. Public Health, 121, 540-545.

Blenkharn, J.I., 2007. Lowering standards of clinical waste management: do the hazardous waste regulations conflict with the CDC's universal/standard precautions?, Journal of Hospital Infection 62, 467-472.

Brewer. B, Antell .A, 2013. A case study of the management of hazardous waste drugs in a large university hospital,http:// dx.doi.org/10.1016/j.jchas. 10.003

Bureau of National Health Insurance, National Health Insurance Annual Statistical Report ,Bureau of National Health Insurance,2003, Taiwan, R0C.

Cheng, Y.W., Sung, F.C., Yang, Y., Lo, Y.H., Chung, Y.T., Li, K.-C, 2009, Medical waste production at hospitals and associated factors, Waste Management, 29: 440-444.

Cheng, Y.W., Sung, F.C., Yang, Y., Lo, Y.H., Chung, Y.T., Li, K.-C., 2009. Medical waste Production at hospitals and associated factors. Waste Management, 29, 440- 444.

Clair N. Sawer, McCarty .Perryl, 2003. Chemistry for Environmental Engineering and Science, McGraw -Hill

Dehghani. M.H, Azam, K., Changani, F., DehghaniFard.E., 2008, Assessment of medical waste management in educational hospitals of Tehran University Medical Sciences. Iranian Journal of Environmental Health Science and Engineering, 5(2): 131-136.

Drug and Related waste, 2015. Government of south Austeralia Cytotoxic epa.gov/opptintr/exposure/pubs/episuitedl.htm (accessed 1.11.13.).

Farzadkia .M, Moradi.A, Shah Mohammadi.M., Jorfi.S, Hospital waste management status in Iran: a case study in the teaching hospitals of Iran, 2009, University of Medical Sciences. Waste Management and Research, 27: 384-389.

Ferrando-Climent. L, S. Mozaz. R, Barcel. D, 2014. Incidence of anticancer drugs in an aquatic urban system: From hospital effluents through urban wastewater to natural environment, Environmental Pollution 193, 216e223
Ferreira. V, Ribau Teixeira. S, 2010. Healthcare waste management practices and risk perceptions: Findings from hospitals in the Algarve region, Portugal, Waste Management 30. 26572663

Jang, Y.C., Lee, C., Yoon, O.S., Kim, H., 2006, Medical waste management In Korea. Journal of Environmental Management, 80: 107-115.

Jean-Philippe Besse, Jean-François Latour, Jeanne Garric. 2012. Anticancer drugs in surface waters, what can we say about the occurrence and environmental significance of cytotoxic, cytostatic and endocrine therapy drugs? 2012- Environment International 39. 7386

Johannessen.L.M, Dijkman.M, Bartone.C, Hanrahan.D, Boyer.M.G, Chandra, C., 2000. Health Care Waste Management Guidance Note. The World Bank, Washington, DC.

Mehrdad Askarian, Peigham Heidarpoor, Ojan Assadian, 2010. A total quality management approach to healthcare waste management in Namazi Hospital, Iran. waste Management, 2010, 30, 2321-2326

Nussbaumer. S, Bonnabry. P, Jean-Luc Veuthey, Fleury-Souverain. S, 2011. Analysis of anticancer drugs: A review, Journal home page: www.elsevier.com/locate/talanta, Talanta 85 , 2265- 2289

Rafiee. A, Nabizadeh. R. 2016. Infectious Waste Management in Imam Khomeini Hospital Complex in Tehran and Recommending Appropriate Managerial Solutions" Journal of Health, Vol. 7, No. 4, autumn, Pages 446-457

Tsakona. M, Anagnostopoulou. E, Gidarakos.E . 2010. Hospital waste management and toxicity evaluation: A case study. Waste Management 27. 912-920

U.S. EPA, 2013. Exposure Assessment Tools and Models. EPI Suite v4.1. http://www.

Vijay R, Puneet G. and M C Joshi, Practical guidelines for disposing cytotoxic waste. India's No.1 Weekly for the Pharmaceutical Industry

Voudrias. E, Goudakou.L, Kermenidou. K, Softa. A, 2012. Composition and production rate of pharmaceutical and chemical waste from Xanthi General Hospital in Greece, Waste Management 32. 1442-1452

WHO, 2014. Safe management of wastes from Health-care activities. 2nd edition.

Zhang.J, Victor .W.C, Chang, 2013. Removal of cytostatic drugs from aquatic environment: A review, 2013- Science of the Total Environment 445-446. 281-298 